\title{
Effects of plant pathogens on population dynamics and community composition in grassland ecosystems: two case studies
}

Article

Accepted Version

Jeger, M. J., Salama, N. K. G., Shaw, M. W., van den Berg, F. and van den Bosch, F. (2013) Effects of plant pathogens on population dynamics and community composition in grassland ecosystems: two case studies. European Journal of Plant Pathology, 138 (3). pp. 513-527. ISSN 0929-1873 doi: https://doi.org/10.1007/s10658-013-0325-1 Available at https://centaur.reading.ac.uk/35411/

It is advisable to refer to the publisher's version if you intend to cite from the work. See Guidance on citing.

To link to this article DOI: http://dx.doi.org/10.1007/s10658-013-0325-1

Publisher: Springer

Publisher statement: This is the pre-publication version. The published article, which has been copy-edited and may contain other corrections is available at http://link.springer.com/article/10.1007\%2Fs10658-013-0325-1

All outputs in CentAUR are protected by Intellectual Property Rights law, including copyright law. Copyright and IPR is retained by the creators or other copyright holders. Terms and conditions for use of this material are defined in the End User Agreement. 


\section{www.reading.ac.uk/centaur}

\section{CentAUR}

Central Archive at the University of Reading

Reading's research outputs online 


\title{
Effects of plant pathogens on population dynamics and community composition in grassland ecosystems: two case studies
}

\author{
Jeger $\mathrm{MJ}^{1}$, Salama $\mathrm{NKG}^{1}$, Shaw $\mathrm{MW}^{2}$, van $\operatorname{den} B \operatorname{Berg} \mathrm{F}^{3}$, van $\operatorname{den}$ Bosch $\mathrm{F}^{3}$, \\ ${ }^{1}$ Division of Ecology and Evolution and Centre for Environmental Policy, Imperial College London, \\ Silwood Park campus, Ascot SL5 7PY, United Kingdom \\ ${ }^{2}$ School of Biological Sciences, University of Reading, Early Gate, Reading RG6 6AS, United Kingdom \\ ${ }^{3}$ Biomathematics and Bioinformatics, Rothamsted Research, Harpenden AL5 2JQ, United Kingdom
}

\begin{abstract}
Grassland ecosystems comprise a major portion of the earth's terrestrial surface, ranging from high-input cultivated monocultures or simple species-mixtures to relatively unmanaged but dynamic systems. Plant pathogens are a component of these systems with their impact dependent on many interacting factors, including grassland species population dynamics and community composition, the topics covered in this paper. Plant pathogens are affected by these interactions and also act reciprocally by modifying their nature. We briefly review these features of disease in grasslands and then introduce the 150-year long-term Park Grass Experiment (PGE) at Rothamsted Research in the UK. We then consider in detail two plant-pathogen systems present in the PGE, Tragopogon pratensis-Puccinia hysterium and Holcus lanata-Puccinia coronata. These two systems have very different life history characteristics: the first, a biennial member of the Asteraceae infected by its host-specific, systemic rust; the second, a perennial grass infected by a host-nonspecific rust. We illustrate how observational, experimental and modelling studies can contribute to a better understanding of population dynamics, competitive interactions and evolutionary outcomes. With Tragopogon pratensis-Puccinia hysterium, characterised as an "outbreak" species in the PGE, we show that pathogen-induced mortality is unlikely to be involved in host population regulation; and that the presence of even a short-lived seed-bank can affect the qualitative outcomes of the host-pathogen dynamics. With Holcus lanata-Puccinia coronata, we show how nutrient conditions can affect adaptation in terms of host defence mechanisms, and that coexistence of competing species affected by a common generalist pathogen is unlikely.
\end{abstract}

Keywords grassland species dynamics, pathogen dynamics, pathogen-induced mortality, seed bank, nutrient supply, competitive interactions, evolution of host defence

\section{Introduction}

Grassland comprises a major component of global terrestrial ecosystems: excluding Greenland and Antarctica, perhaps some $40 \%$ of the earth's terrestrial surface. Grassland evolution can be considered a biological force for global change through the co-evolution of grasses and their grazers over geological time (Retallack, 2013). Grassland ecosystems range from simple cultivated grasslands used as rotational or semi-permanent leys for grazing livestock to relatively undisturbed or intentionally-conserved systems. Biodiversity in grassland ecosystems can be low, as in monocultures or simple grass/legume mixtures, or high as in extensive pastoral range-lands or 
protected reserves such as the US prairies. Throughout this spectrum of land use there are associated communities of organisms, with varying levels of diversity depending on geography and history. These communities include other flora, microbes, invertebrates, and vertebrates including mammals, reptiles, and birds, all of which interact in various ways and with surrounding patterns of land use, e.g., agricultural systems and forestry.

Much of the scientific literature on the impact of pathogens and pests on plant populations and communities and factors which mitigate the impact has come from work with forage production and grazing lands; for example, Nelson and Burns (2006) reviewed the advances in grassland science over the last 50 years and documented how management has benefitted from advances in disease resistance and an understanding the role of endophytic fungi. There has been little consideration of the impact of pathogens in relatively unmanaged grassland ecosystems, except in the context of global/climate change and biodiversity (Chakraborty 2001; Pautasso et al. 2010). Many reviews have appeared at regular intervals that document the impacts of pathogens on natural or unmanaged plant populations and communities in general (e.g., Dinoor and Eshed, 1984; Kranz, 1990; Alexander \& Holt, 1998; Alexander, 2010; Burdon et al., 2013, amongst others) but, despite many specific experimental studies, there appears to be no major overview that integrates the body of knowledge on grassland diseases obtained from these studies. Such a comprehensive review is beyond the scope of the present paper but selected examples of experimental studies that illustrate the wealth of information available on different aspects are given in Table 1.

Plant pathogens (fungi, oomycetes, bacteria, and viruses) are present in all grassland ecosystems. They may directly alter population dynamics of individual plant species and the competitive effects affecting community composition in grasslands. We give examples of research carried out on these two topics and then look in more detail at two specific examples: the grass Holcus lanatus and the composite Tragopogon pratensis, as affected by rust pathogens, but with differing life history characteristics in both host and the rust species. We do this in the context of long-term experiments on nutrient regimes affecting the population dynamics of host species in the Park Grass Experiments (PGE) at Rothamsted Research, UK, and for each example we consider observational, modelling and experimental approaches which manipulate the interactions involved.

\section{Effects of pathogens on plant population dynamics}

Disease development in relation to plant host characteristics

Disease development in grassland species can be influenced by host reproduction characteristics, morphology, and vegetative development. Systemic disease spread has been suggested as a disadvantage for clonal growth patterns in grasses. A mathematical model has been constructed to determine whether systemic disease decreases the competitive ability of highly integrated clonal plants when compared with less integrated ones (Koubek and Herben 2008). The model was constructed to represent grass ramets in short-turf grasslands, such as Festuca rubra. Although the same infection rate caused more systemic disease in the highly integrated plants, the disease had only limited potential to select for a less integrated strategy due to the advantages in clonal integration, such as greater translocation ability and resource sharing. 
Fungal disease affecting seed has rarely been quantified in grassland ecosystems. Seed mortality of four prairie species (two grasses and two forbs) was studied in relation to causal factors (Clark and Wilson 2003). "Natural" mortality not associated with fungal disease or vertebrate predation (44$80 \%$ ) was the greatest factor, much greater than fungal disease $(<10 \%)$. Vertebrate and invertebrate seed predation (not directly measured) was important only in single species.

The effects of insect herbivores (by insecticide) and fungal pathogens (by fungicide) exclusion on population-level seed production of four grass species was studied over two years in Minnesota (Dickson and Mitchell 2010). There were no interactive effects but seed production of all four species was affected by either herbivore or pathogen exclusion. Reduced seed production by dominant species may promote co-existence with sub-dominant species through competitioncolonization trade-offs. Seed yield losses are an important consideration in managed grasslands (Pfender and Alderman, 2006).

Fungal endophyte interactions with host plants have a range of effects, both beneficial and detrimental, on host reproduction and development. The fungal endophyte Epichloë bromicola causes choke disease on Bromus erectus. A 3-year field experiment was conducted at a site in the Swiss Jura Mountains where, overall, $4.3 \%$ of tillers had diseased inflorescences under conditions of small-scale habitat fragmentation (Groppe et al. 2001). After fragmentation, disease incidence increased at the level of the individual plant (genet), probably due to increased horizontal transmission of disease, but at the level of the tiller disease incidence was decreased due to an increase in healthy tillers. Species of Epichloë infect Holcus lanatus and $\mathrm{H}$. mollis, but insecticideexclusion experiments in grassland sites at Silwood Park in the UK gave contrasting results for these two grass species (Clay and Brown 1997): insect herbivory seemed to increase infection in H. mollis, but decrease it in $\mathrm{H}$. lanatus. Leaf wounds caused by insects were important sites for infection of orchard grass by Epichloë typhina (Alderman, 20013), and slugs are also thought to play a potential role in both stroma fertilisation and disease spread (Hoffman and Rao, 2013).

One of the longest studied grassland communities is the Park Grass experiment (PGE) at Rothamsted Research, Harpenden, UK (Silvertown et al. 2006) (Fig.1). Since 1856, surveys of the plant community structure have been undertaken regularly (also soil microbe responses: see Rousk et al. 2011). As a consequence, long term assessments of the population dynamics of grassland species have been possible. Dodd et al (2005) characterised species as increasing (e.g. Trifolium pratense), decreasing (e.g. Veronica chamaedrys), fluctuatating (e.g. Conopodium majus), or following a sporadic outbreak pattern (e.g. Tragopogon pratensis). Many of these patterns in dynamics were originally assumed to be a result of the fertiliser treatment regimes applied to the plots or to be general population changes. The effect of plant pathogens was not considered. Although the surveys provide good data relating to host plant species incidence, there are no records of disease.

Case study: Tragopogon pratensis - Puccinia hysterium

Tragopogon pratensis is a biennial (Qi et al. 1996) member of the Asteraceae that occasionally demonstrates perennial characteristics (Jorritsma-Wienk et al. 2007) and is host to the autecious demicyclic rust Puccinium hysterium. The life cycle is shown schematically in Fig. 2. Basidiospores infect first year seedlings but symptoms are not observed until the second year as the rust becomes systemic and overwinters in the underground stock. As the second-year plant emerges, aecia are 
produced on the stem and leaves. Aeciospores are produced but play no role in the population dynamics, as the second year plants die following seed set. The sequence of events from teliospore to basidiospore and infection of seedlings has not been investigated.

Over the period 2005-2008, observations on the incidence of $P$. hysterium were made in the PGE. Rust infected plants produced fewer seeds and fewer of these germinated (Salama et al 2010). Overall, $P$. hysterium suppresses potential reproduction of $T$. pratensis by a factor of about 30: an infected individual will on average leave two germinated offspring, whereas a healthy individual may produce up to 75 seedlings. Additionally, infected plants produced shorter seeds with longer pappi. However, once germinated, pot experiments gave no evidence for additional seedling mortality due to pathogen infecton (Salama et al 2012). A similar reduced seed production occurs in groundsel (Senecio vulgaris) infected by the rust, $P$. lagenophorae (Paul and Ayres 1987), and altered seed morphology has been observed in cases of Lolium multiflorum infected with $P$. coronata (Mattner and Parbery 2007) and $P$ hordei infecting Hordeum vulgare (Das et al. 2007).

A discrete time epidemiological model was developed (Salama et al 2012) which compartmentalised the host population as: susceptible $(S)$ seedlings, exposed/latently infected $(E)$ seedlings, infectious (I) second-year plants, and healthy second-year plants $(R)$ which no longer contribute to the epidemic (even if infected within-year they do not develop symptoms or contribute to the infection of seedlings). The model captured the essential characteristics of a biennial host and systemic pathogen. The model contained parameters for: seedling recruitment $(a)$; density dependence of seedling emergence $(\lambda)$; within $(b)$ and between $(d)$ year mortality of the host; a Poisson distribution function for pathogen transmission $(c)$; and the probabilities of disease expression $(p)$ and pathogen induced mortality (6).

The model was also adapted to account for variable pathogen-induced mortality and a trade-off between transmissibility and pathogen-induced mortality. For many parameter combinations the frequency of the host varied in a way reminiscent of the observed irregular outbreak dynamics of $T$. pratensis in the PGE (Salama and Jeger, 2013). Other parameter combinations produced steadystate host populations free of disease, cyclical population dynamics of diseased and healthy hosts, and extinction of both the host and pathogen (Salama et al. 2012).

Disease persists in the model population if each infected individual produces at least one other infected individual: that is, if the basic reproductive number $R_{0}>1 . R_{0}$ is determined by a formula including parameters representing pathogen ecology (transmissibility, the probability of disease expression and pathogen-induced mortality) and host ecology (background mortality and host population size). Pathogen-induced mortality directly influences the host population dynamics. It was possible to derive a recurrence relationship between the number of healthy second-year plants and the number of healthy seedling plants two years previously. This relationship was fitted to observational data collected at the PGE (1995 - 2008) (Salama et al. 2012). However, diseaseinduced mortality hardly affected the goodness of fit. Furthermore, the model suggested that in the field, density-dependence in seedling emergence hardly affected the dynamics. Overall, the observational data, pot experiments and model analysis suggests that the dynamics of $T$. pratensis in the PGE results from a moderately performing host exposed to a highly transmissible strain of $P$. hysterium which has a low probability of surviving the systemic phase of its life-cycle, and causes little additional mortality in diseased compared with healthy plants. 
The model above ignores the possible existence of a long-lived seed-bank. For example, in other systems the species Linanthus parryae has a vast seed-bank where seeds remain viable up to six years (Kaj et al. 2001) and Brassica napus up to ten years (Pekrun et al. 2005). This in turn can increase population size, modulate changes in genetic variation (Nunney 2002) and also modify age structure within the population (Evans and Dennehy 2005). Seed-banks have an impact on plant populations by acting as reservoirs of genetic material that transfer across generations, so retaining genes that would otherwise be lost by drift (Waples 2006). A seed-bank allows for the recruitment of individuals irrespective of biotic and abiotic factors which may have affected the previous year's adult stock (Waples 2006), so potentially altering host population dynamics.

There is some evidence for a small seed-bank for T. pratensis (Clements et al. 1999) remaining viable for up to two years (Roberts 1986) but sensitive to anaerobic conditions and temperatures above $25^{\circ} \mathrm{C}$ which reduce seed viability. A seed-bank exists for the related cultivated species $T$. porrifolius (purple salsify) (Haubensak and Smyth (2002). A seed-bank was therefore included in the model above (Salama et al. 2012, Salama and Jeger 2013) and the resulting dynamics investigated. The seed-bank was added as an extra compartment (Fig. 3). This was considered to be reasonable (rather than using a full age structured matrix: Caswell 1989) where the seed-bank is likely to be short lived and have minimal cohort structure. The seed-bank phase $(B)$ receives a constant number of seeds $\left(a_{1}\right)$ from each uninfected adult above ground. A proportion of the belowground seed-bank $\left(a_{0}\right)$ emerges as $S$ individuals each season. Below-ground mortality occurs in the seed-bank both within $\left(b_{0}\right)$ and between season $\left(d_{0}\right)$, whilst background mortality is also experienced by above ground individuals within $\left(b_{1}\right)$ and between season $\left(d_{1}\right)$. Exposed and infected individuals experience pathogen-induced mortality $(B)$ as before.

The revised model can be represented by the following equations which describe the population at the beginning of a growing season. Note that, as in the basic model, there is no exposed class at the start of a season (see Salama 2009 for derivation):

$$
\begin{aligned}
& B_{t+1}=\left[\left(1-d_{0}\right)\left(1-a_{0}\right)\right]\left[\left(1-b_{0}\right) B_{t}+\frac{a_{1}\left(1-b_{1}\right) R_{t}}{1+\left(1-b_{1}\right) \lambda R_{t}}\right] \\
& S_{t+1}=a_{0}\left[\left(1-b_{0}\right) B_{t}+\frac{a_{1}\left(1-b_{1}\right) R_{t}}{1+\left(1-b_{1}\right) \lambda R_{t}}\right] \\
& I_{t+1}=\left(1-b_{1}\right)\left(1-d_{1}\right)(1-\beta) p S_{t}\left[1-e^{-c\left(1-b_{1}\right)(1-\beta) I_{t}}\right] \\
& R_{t+1}=\left(1-b_{1}\right)\left(1-d_{1}\right) S_{t}\left\{1-p\left[1-e^{-c\left(1-b_{1}\right)(1-\beta) I_{t}}\right]\right\}
\end{aligned}
$$

By rearranging the model equations in the absence of disease it is possible to estimate the steady state populations for the seed-bank and non-infected plants. We can then derive an expression describing the conditions required for disease to invade a healthy population: 
This condition involves all of the model parameters. An implicit steady-state equation for infectious individuals $\left(I^{*}\right)$ can be derived as in the basic model (Salama et al. 2012), but this is complex and is not shown.

Using the model framework simulations can be undertaken for a range of parameter values (Table 2) with and without seed-banks. In the case without a seed-bank, host populations may go extinct, tend to a stable population, or undergo continual population cycling with some of the population remaining diseased (Fig.4). Similar patterns also occur when there is a trade-off between transmissibility and pathogen-induced mortality. However, with a seed-bank it appears that extinction is avoided for parameter combinations that would otherwise cause the pathogen to make the host extinct. Fig. 5 demonstrates that under most conditions the host populations tend to a steady population size with disease endemic. Under conditions where a moderate or high performing host population is exposed to a highly transmissible strain which causes little pathogeninduced mortality, the host may persist while the disease goes extinct. In systems without a seedbank, for the same parameter values the pathogen population will cycle indefinitely (Fig. 4). Overall, therefore, the seed-bank is a stabilising factor in the population dynamics of both host and pathogen.

The $T$. pratensis $-P$. hysterium system in the PGE demonstrates that it is possible for rust pathogens to significantly alter the recruitment of a host plant by reducing the production and viability of seed. The simulations highlight that, depending on conditions, host populations may be stable with or without a persistent pathogen population, may cycle, or may be driven extinct by the pathogen. However, a seed-bank makes it unlikely that the pathogen will drive the host extinct, despite its dramatic effect on fecundity. These findings are consistent with the episodic appearance of an outbreak host species above ground.

\section{Effect of pathogens on plant community composition}

Diversity, competition and co-existence in grassland communities

The evidence that plant species diversity decreases the severity of plant diseases is strengthening in agricultural systems, but is still sparse for complex plant communities. Roscher et al. (2007) varied the levels of species richness and functional group richness in experimental grassland communities. Different cultivars of Lolium perenne were used to identify effects of plant and cultivar diversity on the incidence and severity of Puccinia coronata and P. graminis. Cultivar monocultures showed strong differences in disease severity. Disease severity of both rusts decreased with increasing species richness and populations of both retained a high level of host specificity. Differences in cultivar susceptibility persisted in the polycultures independent of diversity treatment and host density, but there were cultivar-specific patterns of disease across the species richness gradient.

A long-term manipulative field experiment was used to investigate how environmental factors, fertilization and plant community diversity affect plant traits and herbivore/pathogen damage in the 
common prairie legume Lespedeza capitata (Lau et al. 2008). Plants growing in polyculture were damaged considerably less by specialist herbivores and by pathogens, but had five times more damage from generalist herbivores than when growing in monocultures. Differences in plant traits partly explained the differences in herbivory in relation to diversity but did not explain the differences in disease incidence between monocultures and polycultures.

In a prospective study of alpine grasslands being converted to agricultural use, observations were made of the damage caused by herbivory and fungal pathogen infection in relation to plant functional group (legumes, herbs and grasses), land use (mowed, grazed or abandoned) and altitude (Fischer et al. 2012). Damage by pathogens was independent of land use and altitude but pathogen diversity decreased with fertilization. There was no correlation between damage caused by herbivory or fungal disease with plant species diversity.

Two introduced cultivated genotypes of Lolium perenne were introduced into semi-natural grassland to investigate whether a genotype selected for resistance to Puccinia coronata showed better establishment than a susceptible genotype (Erneberg et al. 2008). Introduced genotypes had greater shoot biomass in the semi-natural plant communities when exposed to pathogen attack, but showed the expected reduction in growth when inoculated onto monoculture pots in a controlled setting.

Much has been learnt by a programme of research in Minnesota since the early 1990s on foliar fungal pathogens in grassland communities. This research has resulted in papers describing diversityproductivity relationships (HilleRis Lambers et al. 2004), $\mathrm{CO}_{2}$ and nitrogen deposition (Mitchell et al, 2003), net production (Mitchell, 2003), species diversity, abundance and composition (Mitchell et al. 2002; Knops et al. 1999) and other topics which cannot be reviewed within the scope of this paper. However, it remains true that little is known about the role of foliar fungal pathogens as drivers of plant community composition and diversity in grasslands. Pesticides may have non-target effects. Most workers attempt to allow for these by testing their effects on yield in potted plants; clearly a significant result in such an experiment means the pesticide's effect on a community needs to be interpreted with care. However, a non-significant result does not mean important side-effects are absent: effects may be undetectable due to inter-replicate variation, may occur only under particular stresses, or may only come into play in competition with other species. Peters and Shaw (1996) manipulated rust severity on Holcus lanatus in a replicated plot experiment using early succession communities created by tillage of existing grassland. Although there were indirect effects of fungicide, it was also possible to show that more severe rust reduced the dominance of the grass and increased the abundance of forbs in the community. Similarly, Allan et al. (2010) used fungicide to exclude pathogens from perennial grassland, as well as vertebrate and invertebrate herbivores. It was possible to quantify their effects compared with the herbivores. Foliar fungal pathogens substantially reduced above-ground plant biomass and promoted plant diversity, similar in effect to the other herbivores but with differential responses of plant species.

A stochastic model was developed to predict the effect on competing species in plant communities of a shared natural enemy that limits recruitment (Schoolmaster 2008). The interactions between natural enemies and recruitment limitation led to some counter-intuitive results. For example, in a competitive interaction it is neither necessary nor sufficient for a shared natural enemy to reduce growth of the better competitor more than the poorer competitor for the presence of the enemy to 
have an overall positive effect on the poorer competitor. This applies especially where there is short scale dispersal and fecundities are low, which emphasises the importance of considering spatial processes in models of plant community dynamics. Host range differences between populations of pathogen species may also be important, for example with Puccinia graminis subsp. graminicola populations from perennial ryegrass and tall fescue (Pfender, 2001).

A spatiotemporal model of the transmission dynamics of cereal yellow dwarf viruses was used to examine the effects of seasonality and plant competition, and whether the suite of viruses can persist across a range of plant community spatial structures (Moore et al. 2011). The ability of a pathogen to invade a fragmented community with different levels of patch connectivity was examined, as was the extent to which a pathogen could facilitate the establishment of a newly arrived host species. Connectivity interacts with the arrival time and host "infection tolerance" in determining whether establishment will occur.

These examples are of foliar pathogens. Competitive effects affecting plant populations are claimed to maintain diversity in plant populations particularly strongly through "Janzen-Connell effects", where these are widespread and sufficiently strong enough (Fitzsimons and Miller, 2010; Petermann et al., 2008) to promote species co-existence by preventing the continued occupation of a site by one species. The general mechanism proposed for this is the build up of soil-borne pathogens which reduces the competitive ability of single species and balances out differences in individual fitness among species. An example has been claimed in the sand-dune grass Vulpia ciliata (Carey et al., 1992); the phenomenon of "clover decline" or "clover sickness" (also a subject of a long-term experiment in the early days of Rothamsted) is due to a variety of root pathogens and pests and would occur in dense stands in natural as well as planted grassland.

Grassland ecosystems function as dynamic plant communities, even in the simplest case of binary grass-legume mixtures. In these communities the competitive outcomes between species can be modified, even reversed, in the presence of pathogens affecting one or more of the component species. Plant species may adapt in their resistance levels to pathogens with a trade-off involving a reduction in growth rate (van den Berg and van den Bosch 2009). This has implications for coexistence of competing plant species, as discussed in the case study of Holcus lanata-Puccinia coronata.

\section{Case study : Holcus lanatus - Puccinia coronata}

The evolution in grasses of traits due to selection by pathogen attack is likely to alter competitive outcomes. Apical leaf necrosis or leaf shedding has been modelled (van den Berg and van den Bosch, 2004) as an adaptive response to disease pressure. Infection-driven leaf shedding was shown to be a more efficient response to pathogen attack than constant leaf shedding. Both strategies imply increased shedding rates if nutrients are more available. Which strategy will evolve depends on the balance of autoinfection (infections on the same plant) and alloinfection (infection of other plants). Study of these strategies was further developed by van den Berg et al. (2007). When nutrient availability is high, and assuming plants are more susceptible as a consequence, there will be a higher $\mathrm{N}$ drain by the pathogen and hence faster apical leaf necrosis. For a biotrophic pathogen this will reduce the disease load as the pathogen cannot grow on necrotic tissue. For apical leaf necrosis to be a successful defence mechanism the benefits of disease reduction by early leaf necrosis must 
be greater than the costs of losing healthy leaf tissue, the source of assimilates for plant growth. These costs should be lower if exogenous nutrients are more freely available.

Experimental work was then conducted with the grass Holcus lanatus, a common species in the PGE (van den Berg et al. 2008). Seeds of the grass and urediniospores of Puccinia coronata, a rust with many graminaceous hosts, were collected from adjacent plots in the PGE, similar in habitat but with differing $\mathrm{N}$-fertilization regimes that had been applied for 150 years. In a factorial design with all combinations of treatments present, seeds from each plot were grown in pots under regimes similar to one of the original nutrient conditions and inoculated with urediniospores collected from one of the original plots. The time of disease onset was noted and the population growth rate on leaves calculated. The experiment was repeated in two years. With higher nutrient availability, disease onset was earlier and the population growth rate was higher, but the size of these effects depended on both pathogen and seed origin. Higher nutrient availability also led to a reduced time between disease onset and apical leaf necrosis onset (assumed to result from pathogen attack), with some indication that necrosis mechanisms were influenced by the origin of the seed and pathogen. The findings were consistent with apical leaf necrosis being a defence mechanism.

The implications of the evolution of adaptive traits such as defence mechanisms for co-existence of plant species were further analysed by van den Berg and van den Bosch (2009). They studied a model, shown schematically in Fig.6, for the dynamics of two plant species competing for space that are both infected with a generalist pathogen. The model is governed by the equations

$$
\begin{aligned}
& \frac{d X}{d t}=r_{X} X-\alpha_{x} X^{2}-\alpha_{Y} X Y-\beta_{X} I X \\
& \frac{d Y}{d t}=r_{Y} Y-\alpha_{Y} Y^{2}-\alpha_{X} X Y-\beta_{Y} I Y \\
& \frac{d I}{d t}=\beta_{X} I X+\beta_{Y} I Y-\omega I
\end{aligned}
$$

Here $X$ and $Y$ are the densities of the two plant species and $I$ is the total density of infected plants. The intrinsic rate of increase of the densities $X$ and $Y$ of the plant species are denoted by $r_{X}$ and $r_{Y}$, respectively. The competitive ability of plant species $X$ and $Y$ are measured by $\alpha_{X}$ and $\alpha_{Y}$, respectively. The generalist plant pathogen has infection parameters $B_{X}$ and $B_{Y}$ on species $X$ and $Y$, respectively. Plants remain infectious for, on average, $1 / \omega$ time units. The model was analysed first with fixed parameters, ignoring the evolution of defences. It predicts that:

(i) In the absence of the pathogen the two plant species do not co-exist and the plant species with the largest rate of increase outcompetes the other plant species. This is a well known result for competition for space.

(ii) In the presence of disease there is a wide range of parameters for which the two plant species can co-exist.

These are well-established properties for species that compete and are infected by a generalist disease, as discussed above. Next, the consequences of variation, allowing the defensive capacity of the plant species to evolve, were investigated. It is reasonably well established (e.g. Ruuhola and 
Julkunen-Tiitto 2003; Way et al. 2002) that there is often a trade-off between defence against pathogen infection and the growth rate of plants. This trade-off is incorporated into the model using a simple energy budget calculation (Fig. 7) resulting in a hyperbolic relation between plant growth rate and infection efficiency of the pathogen:

$\beta_{i}=\beta_{0 i} e^{-A_{i}\left(1-B_{i} r_{i}\right)}$

Here the subscript $i$ denotes plant species $X$ or $Y . A_{i}, B_{i}$ and $B_{0 i}$ are parameters in the energy budget model. In the model, the defence capacity of both species evolves over time subject to the condition that increasing defence decreases the plant species growth rate, and so its capacity to compete for space. Surprisingly, for any set of parameter values for which the plant species can coexist in the static-trait ecological model, plant defences evolve such that the species can no longer co-exist.

The conclusion from these modelling studies is therefore that - despite frequency dependent infection by generalist pathogens playing an important role in promoting plant species coexistence on an ecological time scale - long term species coexistence as observed in many natural plant communities cannot be explained by such a mechanism (van den Berg and van den Bosch, 2009). The question is then what mechanisms may lead to so many plant species coexisting. In practice, completely generalist pathogens are unusual: in many cases cryptic or partial specialisation on particular hosts exists, even below species level. This is true, for example, in the Holcus - Puccinia coronata coronata system (Dawkins, 1988). It might therefore be useful to extend these models to include the possibility of evolution in the pathogens, driven by trade-offs between pathogenicity on the two hosts.

\section{Conclusions}

This paper does not survey the full range of grassland ecosystems across a range of temporal and spatial scales. However the selected examples and case studies presented in this paper allow for some conclusions to be drawn about the relationship between plant pathogens, host population dynamics and diversity, and disease dynamics.

1. Studies on grassland diseases benefit from combining observational, experimental and modelling approaches.

2. Disease-induced mortality is not a necessary condition for host population regulation by plant pathogens.

3. The existence of a seed bank affects the qualitative as well as quantitative dynamics of natural plant populations. This aspect has been relatively understudied in field investigations of the role of disease in such populations.

4. Adaptation and evolutionary change in response to disease alter the ecology and population dynamics of individual species over longer time-scales, and therefore alter community composition and levels of biodiversity in grasslands. 
5. Most attempts to improve grasslands for human purposes involve fertilization. This alters immediate disease levels, and the trajectory of longer-term evolution in response. However, the effects of fertilisation on disease dynamics, plant adaptive responses and grassland species diversity are poorly understood and deserve more study.

6. Co-existence of plant species in natural plant populations on an evolutionary time scale appears not to be wholly explained by mechanisms such as frequency-dependent infection and competitive interactions, although these can be shown to be effective on ecological time scales.

7. A greater dialogue between plant pathologists concerned mostly with disease in managed plant populations and ecologists concerned mostly with disease in natural unmanaged systems would be to the mutual benefit of both. Grasslands, because of the continuum in a broad range of management inputs, make an ideal system for this interchange to take place.

\section{References}

Alderman, S.C. (2013). Survival, germination, and growth of Epichloë typhina and significance of leaf wounds and insects in infection of orchardgrass. Plant Disease, 97, 323-328.

Alexander, H.M. (2010). Disease in natural plant populations, communities, and ecosystems: insights into ecological and evolutionary processes. Plant Disease, 94, 492-503.

Alexander, H. M. \& Holt, R. D. (1998). The interaction between plant competition and disease. Perspectives in Plant Ecology, Evolution and Systematics, 1, 206-220.

Allan, E., van Ruijven, J., \& Crawley, M.J. (2010). Foliar fungal pathogens and grassland biodiversity. Ecology, 91, 2572-2582.

Barnes, C.W. Kinkel, L.L., \& Groth, J.V. (2005). Spatial and temporal dynamics of Puccinia andropogonis on Comandra umbellata and Andropogon gerardii in a native prairie. Canadian Journal of Botany, 83, 1159-2581.

Burdon J.J., Thrall, P.H., \& Ericson, L. (2013). Genes, communities \& invasive species: understanding the ecological and evolutionary dynamics of host-pathogen interactions. Current Opinion in Plant Biology, in press.

Booth, R.E., \& Grime, J.P. (2003). Effects of genetic impoverishment on plant community diversity. Journal of Ecology, 91, 721-730.

Borer, E.T., Hosseini, P.R., Seabloom, E.W., \& Dobson, A.P. (2007). Pathogen-induced reversal of native dominance in a grassland community. Proceedings of the National Academy of Sciences USA, $104,5473-5478$.

Borer, E.T., Seabloom, E.W., Mitchell, C.E., \& Power, A.G. (2010). Local context drives infection of grasses by vector-borne generalist viruses. Ecology Letters, 13, 810-818.

Borer, E.T., Adams, V.T., Engler, G.A., Adams, A.L., Schumann, C.B., \& Seabloom, E.W. (2009). Aphid fecundity and grassland invasion: Invader life history is the key. Ecological Applications, 19, 11871196. 
Caswell, H. (1989) Matrix population models: construction, analysis, and interpretation. Sinauer Associates, Sunderland

Chakraborty, S. (2001). Grassland plant diseases: management and control. In Proceedings of the XIX International Grassland Congress: Grassland ecosystems: an outlook into the 21st century (Eds Gomide JA, Mattos WRS, DaSilva SC) San Pedro, Brazil, Feb 11-21 2001, pp 223-230.

Clarke, D.L., \& Wilson, M.V. (2003). Post-dispersal seed fates of four prairie species. American Journal of Botany, 90, 730-735.

Clay, K., \& Brown, V.K. (1997). Infection of Holcus lanatus and H. mollis by Epichloe in experimental grasslands. Oikos,79, 363-370.

Clements, D. R., Upadhyaya, M. K., \& Bos, S. J. (1999). The biology of Canadian weeds. 110. Tragopogon dubius Scop., Tragopogon pratensis L., and Tragopogon porrifolius L. Canadian Journal of Plant Science, 79, 153-163.

Das, M., Griffey, C. A., Baldwin, R. E., Waldenmaler, C. M., Vaghn, M. E., Price, A. M., \& Brooks, W. S. (2007). Host resistance and fungicide control of leaf rust (Puccinia hordei) in barley (Hordeum vulgare) and effects on grain yield and yield components. Crop Protection, 26, 1422-1430.

Dawkins GHM, 1988. Plant pathogens and ecological succession. PhD thesis: University of London, Imperial College.

de Jong, M.D., Bourdot ,G.W., \& Powell, J. (2002). A model of the escape of Sclerotinia sclerotiorum ascospores from pasture. Ecological Modelling, 150, 83-105.

Delmiglio, C., Pearson, M.N., Lister, R.A., \& Guy, P.L. (2010). Incidence of cereal and pasture viruses in New Zealand's native grasses. Annals of Applied Biology, 157, 25-36.

Dickson, T.L., \& Mitchell, C.E. (2010). Herbivore and fungal pathogen exclusion affects the seed production of four common grassland species. PLoS One, 5, e12022.

Dinoor, A. \& Eshed, N. (1984). The role and importance of pathogens in natural plant communities. Annual Review of Phytopathology, 22, 443-466.

Dodd, M., Silvertown, J., McConway, K., Potts, J., \& Crawley, M. (1995) Community stability - a 60year record of trends and outbreaks in the occurrence of species in the Park Grass Experiment. Journal of Ecology, 83, 277-285.

Erneberg, M., Strandberg, B., Strandberg, M., Jensen, B.D., \& Weiner, J. (2008). Effects of soil disturbance and disease on the growth and reproduction of Lolium perenne (Poaceae) introduced to semi-natural grasslands. Polish Journal of Ecology, 56, 593-604.

Evans, M. E. K., \& Dennehy, J. J. (2005). Germ banking: Bet-hedging and variable release from egg and seed dormancy. Quarterly Review of Biology, 80, 431-451

Finch, D.D., \& Alexander, H.M. (2011). Variation in plant distributions, plant traits and disease levels across a woodland /grassland ecotone. American Midland Naturalist, 166, 309-324. 
Firbank, L.G., Smart, S.M., Crabb, J., Critchley, C.N.R., Fowbert, J.W., Fuller, R.J., et al. (2003). Agronomic and ecological costs and benefits of set-aside in England. Agriculture Ecosystems \& Environment, 95, 73-85.

Fischer, M., Weyand, A., Rudmann-Maurer, K., \& Stocklin, J. (2012). Omnipresence of leaf herbivory and leaf infection by fungal pathogens in agriculturally used grasslands of the Swiss Alps, but low plant damage. Alpine Botany, 122, 95-107.

Fitzsimons, M.S. \& Miller, M. (2010). The importance of soil microorganisms for maintaining diverse plant communities in tallgrass prairie. American Journal of Botany, 97, 1937-1943.

Frantzen, J. (1994). The role of clonal growth in the pathosystem Cirsium arvense - Puccinia punctiformis. Canadian Journal of Botany, 72, 832-836.

Goodall, J., Witkowski, E.T.F., McConnachie, A.J., \& Keen, C. (2012). Altered growth, population structure, and realised niche of the weed Campuloclinium macrosephalum (Asteraceae) after exposure to the naturalised rust Puccinia eupatorii (Pucciniaceae). Biological Invasions, 14, 19471962.

Groppe, K., Steinger, T., Schmid, B., Baur, B., \& Boller, T. (2001). Effects of habitat fragmentation on choke disease (Epichloe bromicola) in the grass Bromus erectus. Journal of Ecology, 89, 247-255.

Han, X.M., Dendy, S.P., Garrett, K.A., Fang, L., \& Smith, M.D. (2008). Comparison of damage to native and exotic tallgrass prairie plants by natural enemies. Plant Ecology, 198, 197-210.

Haubensak, K. \& Smyth, A. (2002). Tragopogon porrifolius. University of California, Berkley.

Hille Ris Lambers, J., Harpole, W.S., Tilman, D., Knops, J., \& Reich, P.B. (2004). Mechanisms responsible for the positive diversity-productivity relationship in Minnesota grasslands. Ecology Letters, 7, 661-668.

Hoffman, G.D. \& Rao, S. (2013). Association of slugs with the fungal pathogen Epichloë typhina (Ascomyctina: Clavicipitaceae): potential role in stroma fertilisation and disease spread. Annals of Applied Biology, 162, 324-334.

Jenkins, S.N., Waite, I.S., Blackburn, A., Husband, R., Rushton, S.P., Manning, D.C., et al. (2009). Actinobacterial community dynamics in long term managed grasslands. Antonie van Leeuwenhoek International Journal of General and Molecular Microbiology, 95, 319-334.

Jorritsma-Wienk, L.D., Ameloot, E., Lenssen, J.P.M., \& de Kroon, H. (2007). Differential responses of germination and seedling establishment in populations of Tragopogon pratensis (Asteraceae). Plant Biology, 9, 109e115.

Kaj, I., Krone, S. M. \& Lascoux, M. L. (2001). Coalescent theory for seed bank models. Journal of Applied Probability, 38, 285-300.

Koubek, T., \& Herben, T. (2008). Effect of systemic diseases on clonal integration: modelling approach. Evolutionary Ecology, 22, 449-460. 
Knops, J.M.H., Tilman, D., Haddad, N.M., Naeem, S., Mitchell, C.E., Haarstad, J., et al. (1999). Effects of plant species richness on invasion dynamics, disease outbreaks, insect abundances and diversity. Ecology Letters, 2, 286-293.

Kranz, J. (1990). Fungal disease in multispecies plant communities. New Phytologist, 116, 383-405.

Kremer, R.J., Caesar, A.J., \& Souissi, T. (2006). Soilborne microorganisms of Euphorbia are potential biological control agent s of the invasive weed leafy spurge. Applied Soil Ecology, 32, 27-37.

Latch, G.C.M. (1998). Grass endophytes as a model. Sydowia, 50, 213-228.

Lau, J.A., Strengbom, J., Stone, L.R., Reich, P.B., \& Tiffin, 2008. Direct and indirect effects of $\mathrm{CO}_{2}$, nitrogen, and community diversity on plant-enemy interactions. Ecology, 89, 226-236.

Linders, E.G.A., van Damme, J.M.M., \& Zadoks, J.C. (1996). Epidemics of Diaporthe adunca in experimental and in natural populations of Plantago lanceolata and the effect of partial resistance on disease development. Plant Pathology 45, 70-83.

Malmstrom, C.M., McCullough, A.J., Johnson, H.A., Newton, L.A., \& Borer, E.T. (2005). Invasive annual grasses indirectly increase virus incidence in California native perennial bunchgrasses. Oecologia, 145, 153-164.

Malmstrom, C.M., Shu, R., Linton, E.W., Newton, L.A., \& Cook, M.A. (2007). Barley yellow dwarf viruses (BYDVs) preserved in herbarium specimens illuminate historical disease ecology of invasive and native grasses. Journal of Ecology, 95, 1153-1166.

Mattner, S. W. \& Parbery, D. G. (2007). Crown rust affects plant performance and interference ability of Italian ryegrass in the post-epidemic generation. Grass and Forage Science, 62, 437-444.

Mitchell, C.E. (2003). Trophic control of grassland production and biomass by pathogens. Ecology Letters, 6, 147-155.

Mitchell, C.E., Tilman, D., \& Groth, J.V. (2002). Effects of grassland plant species diversity, abundance, and composition on foliar fungal disease. Ecology, 83, 1713-1726.

Mitchell, C.E., Reich, P.B., Tilman, D., \& Groth, J.V. (2003). Effects of elevated $\mathrm{CO}_{2}$, nitrogen deposition, and decreased species diversity on foliar fungal plant disease. Global Change Biology, 9, 438-451.

Moore, S.M., Manore, C.A., Bokil, V.A., Borer, E.T., \& Hosseini, P.R. (2011). Spatiotemporal model of barley and cereal yellow dwarf virus transmission dynamics with seasonality and plant competition. Bulletin of Mathematical Biology, 73, 2707-2730.

Nelson, C.J., \& Burns, J.C. (2006). Fifty years of grassland science leading to change. Crop Science, 46, 2204-2217.

Nunney, L. (2002). The effective size of annual plant populations: The interactions of a seed bank with fluctuation size in maintaining genetic variation. American Naturalist, 60, 195-204. 
Paul, N. D., \& Ayres, P. G. (1987) Survival, growth and reproduction of groundsel (Senecio vulgaris) infected by rust (Puccinia lagenophorae) in the field during summer. Journal of Ecology, 75, 61-71.

Pautasso, M., Dehnen-Schmutz, K., Holdenrieder, O., Pietravalle, S., Salama, N., Jeger, M.J., et al. (2010). Plant health and global change - some implications for landscape management. Biological Reviews, 85, 729-755.

Pekrun, C., Lane, P. W., \& Lutman, P. J. W. (2005). Modelling seedbank dynamics of volunteer oilseed rape (Brassica napus). Agricultural Systems, 84, 1-20.

Petermann, J.S. Fergus, A.J.F., Turnbull, L.A., \& Schmid B. (2008). Janzen-Connell effects are widespread and strong enough to maintain diversity in grasslands. Ecology, 89, 2399-2406.

Peters, J.C., \& Shaw, M.W. (1996). Effect of artificial exclusion and augmentation of fungal plant pathogens on a regenerating grassland. New Phytologist, 134, 295-307.

Pfender, W.F. (2001). Host range differences between populations of Puccinia graminis subsp. graminicola obtained from perennial ryegrass and tall fescue. Plant Disease, 85, 993-998.

Pfender, W.F. \& Alderman, S.C. (2006). Regional development of orchardgrass choke and estimation of seed yield loss. Plant Disease, 90, 240-244.

Pico, F. X., Ouborg, N. J., \& van Groenendael, J. M. (2003). Fitness traits and dispersal ability in the herb Tragopogon pratensis (Asteraceae): Decoupling the role of inbreeding depression and maternal effects. Plant Biology, 5, 522-530.

Power, A.G., Borer, E.T., Hosseini, P., Mitchell, C.E., \& Seebloom, E.W. (2011). The community ecology of barley/cereal yellow dwarf viruses in Western US grasslands. Virus Research, 159, 95-100.

Qi, M. Q., Upadhyaya, M. K., \& Turkington, R. (1996). Reproductive behaviour of natural populations of meadow salsify (Tragopogon pratensis). Weed Science, 44, 68-73.

Retallack, G.J. (2013). Global cooling by grassland soils of the geological past and near future. Annual Review of Earth and Planetary Sciences, 41, 69-86.

Roberts, H. A. (1986). Seed persistence in soil and seasonal emergence in plant species from different habitats. Journal of Applied Ecology, 23, 639-656.

Roscher, C., Schumacher, J., Foitzik, O., \& Schultze, E.D. (2007). Resistance to rust fungi in Lolium perenne depends on within-species variation and performance of the host species in grasslands of different plant density. Oecologia, 153, 173-183.

Rousk, J., Brookes, P.C., \& Bååth E. (2011). Fungal and bacterial growth responses to N fertilization and $\mathrm{pH}$ in the 150-year 'Park Grass' UK grassland experiment.

Rudgers, J.A. \& Orr, S. (2009). Non-native grass alters growth of native tree species via leaf and soil microbes. Journal of Ecology, 97, 247-255.

Salama, N.K.G., Edwards, G.R., Heard, M.S., \& Jeger, M.J. (2011). The suppression of reproduction of Tragopogon pratensis infected by the rust fungus Puccinia hysterium. Fungal Ecology, 3, 406-408. 
Salama, N.K.G. (2009). Regulation of a Biennial Host Plant Population by an Autoecious, Demicyclic Rust Fungus: Puccinia hysterium on Tragopogon pratensis in the Park Grass Experiment. Unpublished $\mathrm{PhD}$ thesis. Imperial College, University of London.

Salama, N.K.G., van den Bosch, F., Edwards, G.R., Heard, M.S., \& Jeger, M.J. (2012). Population dynamics of a non-cultivated biennial plant Tragopogon pratensis infected by the autecious demicyclic rust fungus Puccinia hysterium. Fungal Ecology, 5, 530-542.

Salama, N.K.G., Jeger, M.J. (in press). Pathogen induced mortality and its role in natural plant-rust systems. In Exercises in Plant Disease Epidemiology, 2nd Edition (eds. Stevenson, K, Jeger, MJ) APS Press, Minneapolis.

Schoolmaster, D.R. (2008). Recruitment limitation modifies the net effects of shared enemies on competitively inferior plants. Journal of Ecology 96, 114-121.

Shiba, T., \& Sugawara, K. (2005). Resistance to the rice leaf bug, Trigonotylus caelestialium, is conferred by Neotyphodium endophyte infection of perennial ryegrass, Lolium perenne. Entomologia Experimentalis et Applicata, 115, 387-392.

Schnitzer, S.A., Klironomos, J.N., HilleRisLambers, J., Kinkel, L.L., Reich, P.B., Xiao, K., et al. (2011). Soil microbes drive the classic plant diversity-productivity pattern. Ecology, 92, 296-303.

Seabloom, E.W., Borer, E.T., Jolles, A., \& Mitchell, C.E. (2009). Direct and indirect effects of viral pathogens and the environment on invasive grass fecundity in Pacific Coast grasslands. Journal of Ecology, 97, 1264-1273.

Seabloom, E.W., Borer, E.T., Mitchell, C.E., \& Power, A.G. (2010). Viral diversity and prevalence gradients in North American Pacific coast grasslands. Ecology, 91, 721-732.

Seabloom, E.W., Borer, E.T., Lacroix, C., Mitchell, C.E., \& Power, A.G. (2013). Richness and composition of niche assembled viral pathogen communities. PLoS One, 8, e55675.

Silvertown, J., Poulton, P., Johnston, E., Edwards, G., Heard, M., \& Biss, P. M. (2006). The Park Grass Experiment 1856-2006: Its contribution to ecology. Journal of Ecology, 94, 801-814.

Sjoberg, J., Martensson, A., \& Persson, P. (2007). Are field populations of arbuscular mycorrhizal fungi able to suppress the transmission of seed-borne Bipolaris sorokiniana to aerial plant parts. European Journal of Plant Pathology, 117, 45-55.

Strengbom, J., Nordin, A., Nasholm, T., Ericson, L. (2002). Parasitic fungus mediates change in nitrogen-exposed boreal forest vegetation. Journal of Ecology, 90, 61-67.

Taye, T., Einhorn, G., \& Metz, R. (2004). Parthenium hysterophorus, an invasive species in Ethiopia investigations on the occurrence and on its pathogens. Zeitschrift fur Pflanzenkrankheiten und Pflanzenschutz, 19, 271-278.

van den Berg, F., \& van den Bosch, F. (2004). A model for the evolution of pathogen-induced leaf shedding. Oikos, 107, 36-49. 
van den Berg, F., Robert, C., Shaw, M.W., \& van den Bosch, F. (2007). Apical leaf necrosis and leaf nitrogen dynamics in diseased leaves: a model study. Plant Pathology, 56, 424-436.

van den Berg, F., van den Bosch, F., Powers, S.J., \& Shaw, M.W. (2008). Apical leaf necrosis as a defence mechanism against pathogen attack: effects of high nutrient availability on onset and rate of necrosis. Plant Pathology, 57, 1009-1016.

van den Berg, F., \& van den Bosch, F. (2009). The presence of generalist plant pathogens might not explain the long-term coexistence of plant species. Journal of Theoretical Biology, 257, 446-453.

van Elsas, J.D., Garbeva, P., \& Salles, J. (2002). Effects of agronomical measures on the microbial diversity of soils as related to the suppression of soil-borne plant pathogens. Biodegradation, 13, 2940.

Vignale M.V. et al (2013). Epichloid endophytes confer resistance to the smut Ustilago bullata in the wild grass Bromus auleticus (Trin.). Biological control (in press) DOI 10.1016/j.biocontrol.2013.06.002 Vozenilkova, B., Markova, J., Klimes, F., Kvet J, \& Maskova, Z. (2008). The influence of mountain meadow management on the occurrence of Puccinia perplexans Plow. Journal of Plant Diseases and Protection, 115, 167-171.

Vosenilkova, B., Kobes, M., Klimes, F., Cermak, B., \& Ptacnikova, V. (2007). The aim of small-site experiments carried out in the area of the foothills of the Sumava Mts. was to determine the etiological agent of the disease of meadow peavine (Lathyrus pratensis L.). Gesunde Pflanzen, 59, 179-182.

Waples, R. S. (2006). Seed banks, Salmon and sleeping genes: effective population size in semelparous, age structures species with fluctuating abundance. American Naturalist, 167, 118-135. Wenström, A. (1999). The effect of systemic rusts and smuts on clonal plants in natural systems. Plant Ecology, 141, 93-97. 
1

2

3

4

5

6

7

8

9

10

11

12

13

14

15

16

17

18

19

20

21

22

23

24

25

26

27

28

29

30

31

32

33

34

35

36

37

38

39

40

41

42

43

44

45

46

47

48

49

50

51

52

53

54

55

56

57

58

59

60

61

62

63

64

65

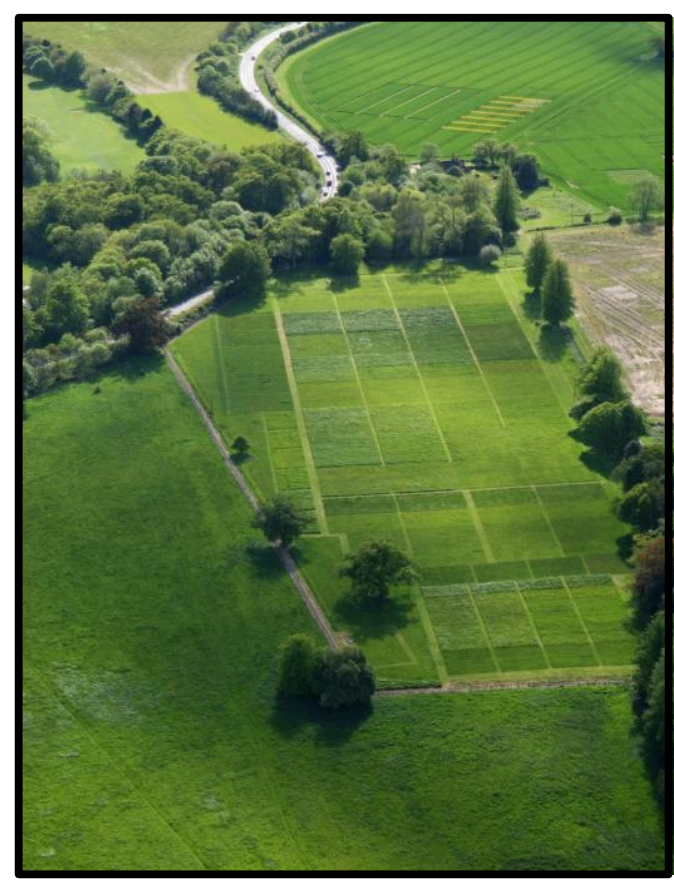

Fig.1 The Park Grass Experiment at Rothamsted Research, Harpenden, UK. 
1

2

3

4

5

6

7

8

9

10

11

12

13

14

15

16

17

18

19

20

21

22

23

24

25

26

27

28

29

30

31

32

33

34

35

36

37

38

39

40

41

42

43

44

45

46

47

48

49

50

51

52

53

54

55

56

57

58

59

60

61

62

63

64

65

First year plants die-bach and Pycnia remain

overwinter

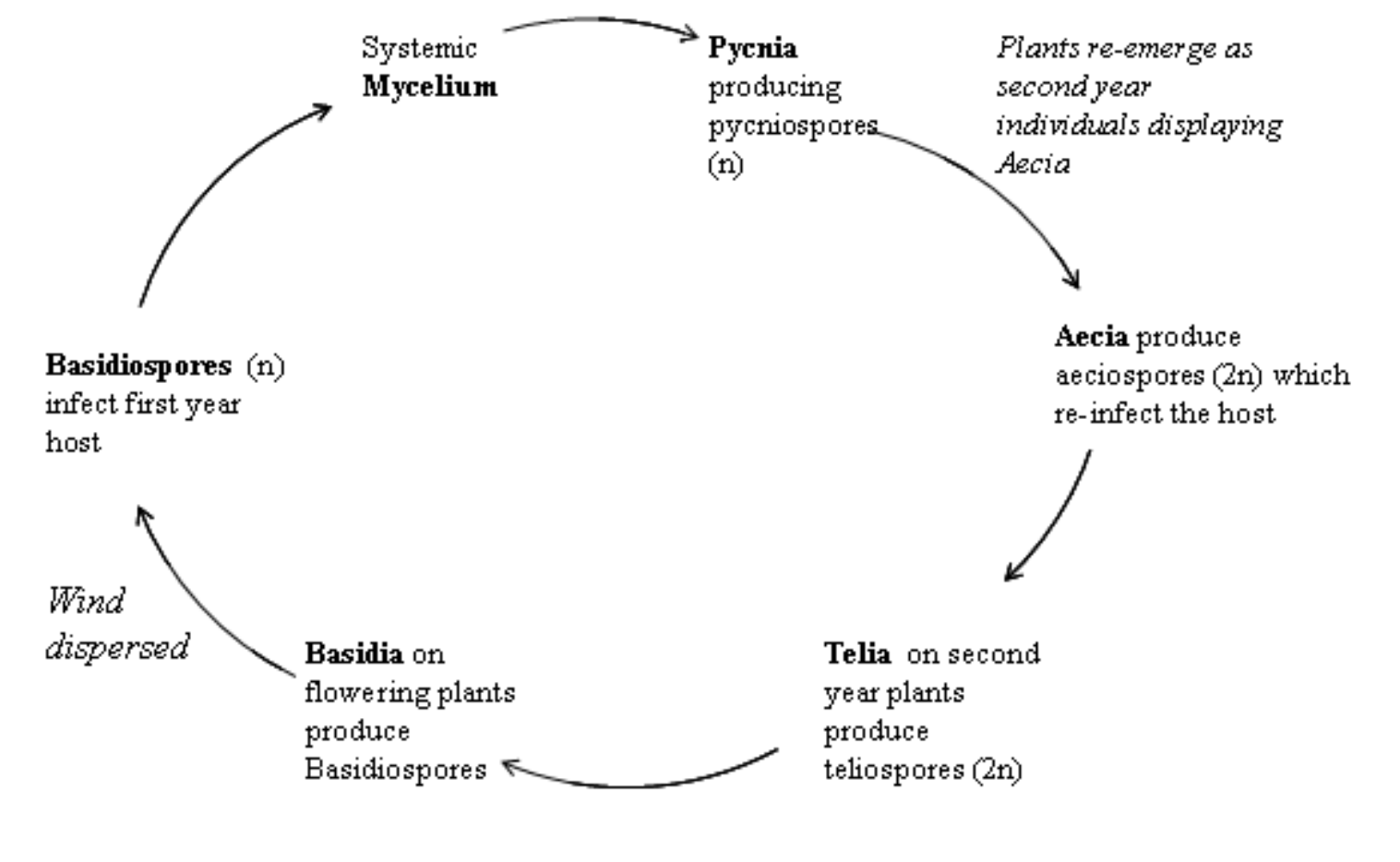

Fig. 2. The life-cycle of $P$. hysterium ( $\mathrm{n}=$ haploid, $2 \mathrm{n}=$ diploid). 


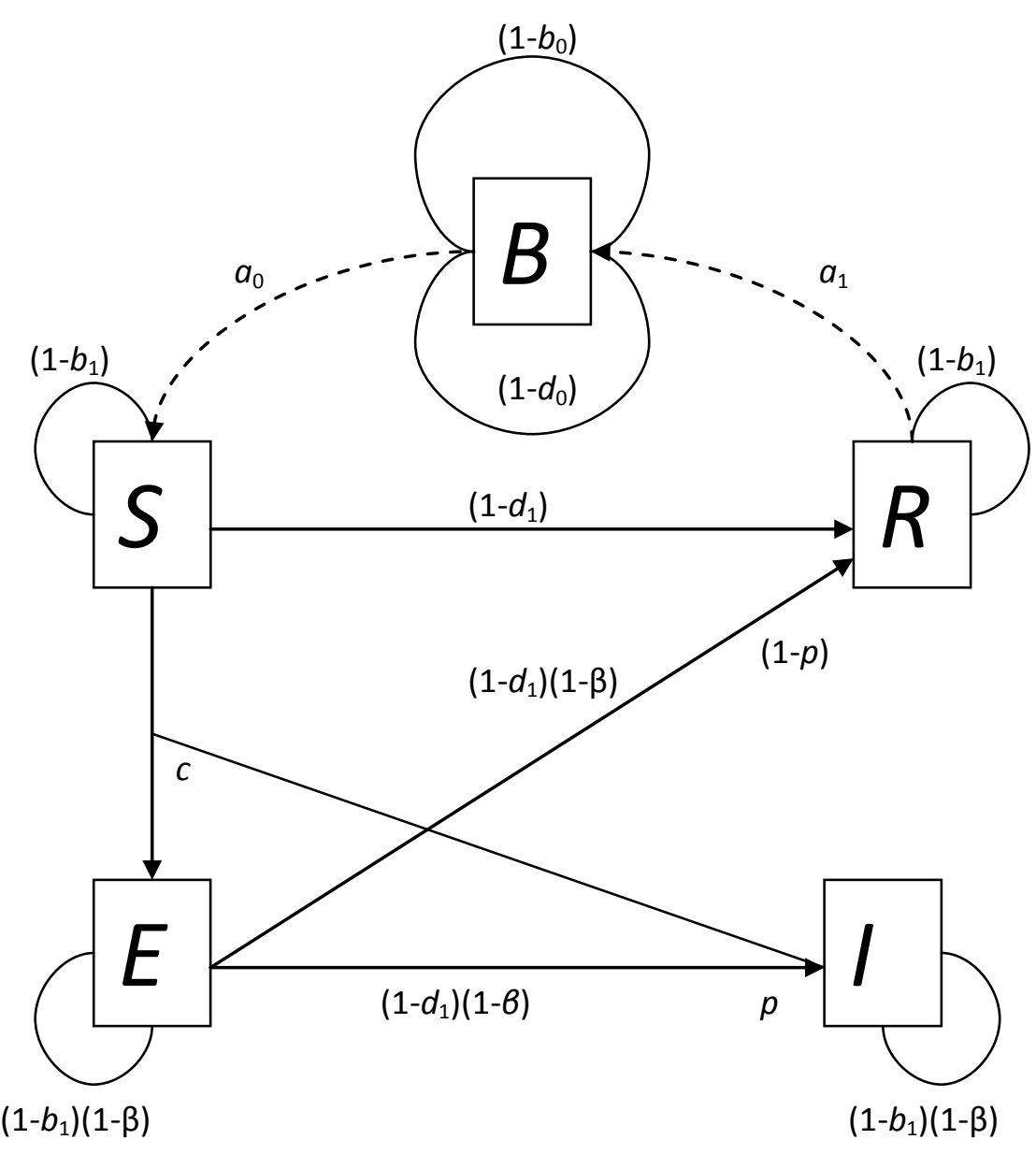

Fig. 3. A schematic representation of the Tragopogon pratensis-Puccinia hysterium model structure with a seedbank phase $(B)$ in addition to the susceptible $(S)$, latently infected $(E)$, infectious $(I)$ and the removed $(R)$ components of the above-ground host population. 
Host

$\mathrm{L}$

$\mathrm{L}$

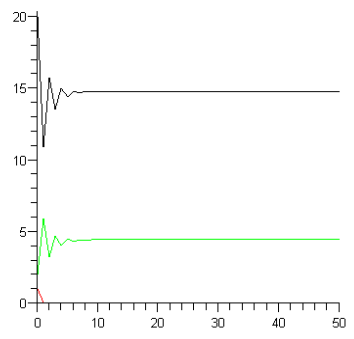

M

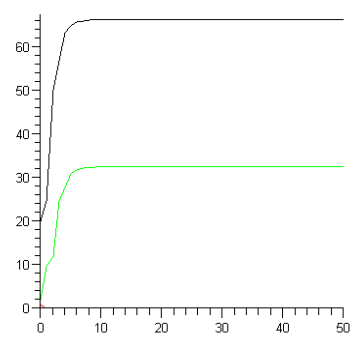

$\mathrm{H}$

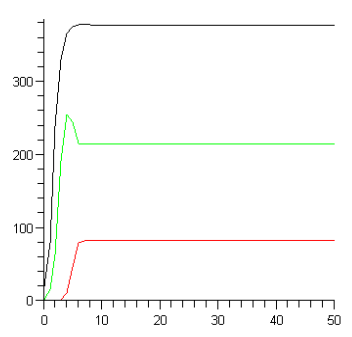

Disease

M
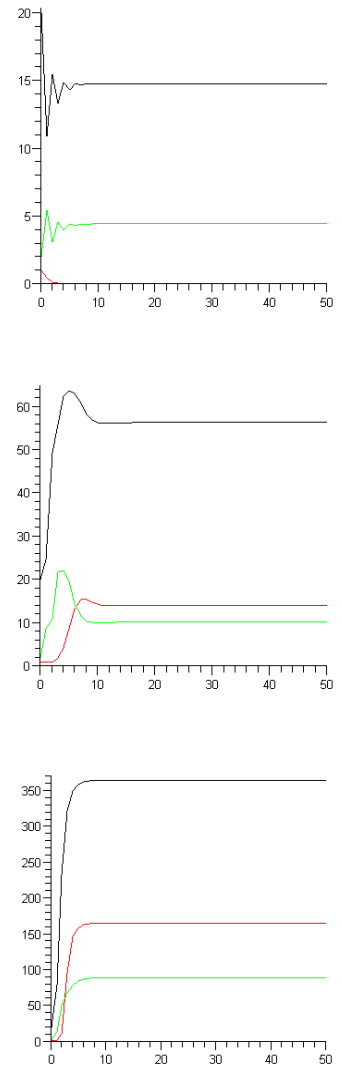

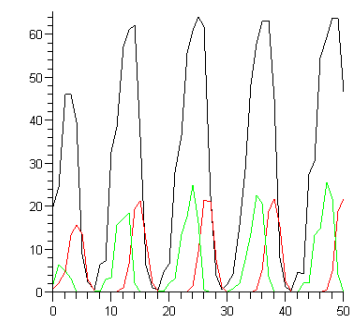

$\mathrm{H}$
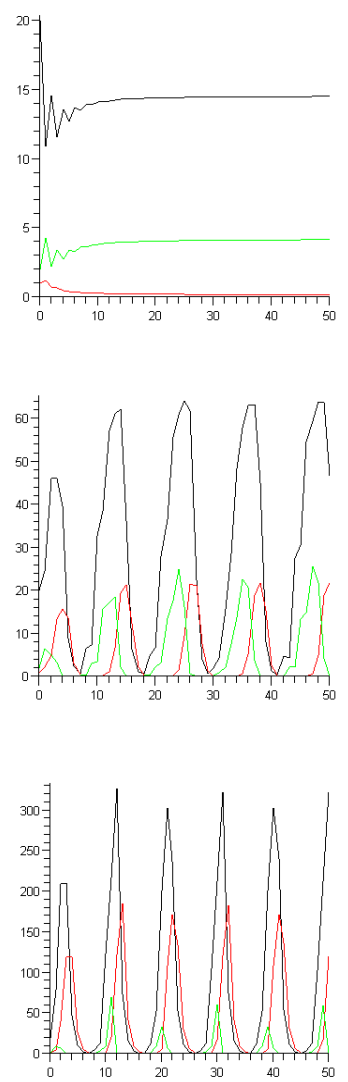

Fig. 4. Simulations produced under conditions of high, medium and low host performance and pathogenicity in the Tragopogon pratensis-Puccinia hysterium system. Each simulation represents - $\mathrm{S},-\mathrm{I},-\mathrm{R}$ dynamics. 
Host

L

L

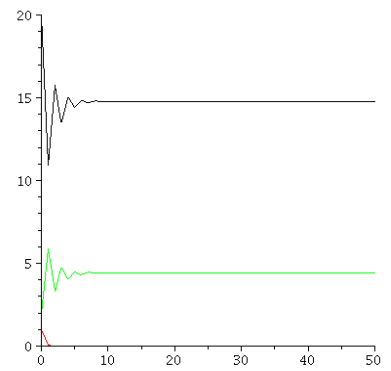

M

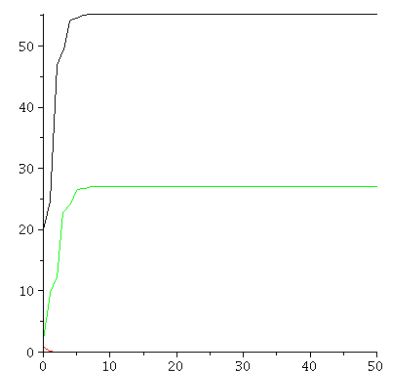

H

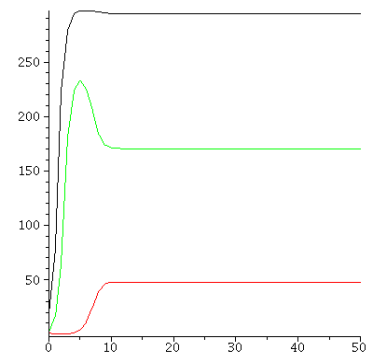

Disease

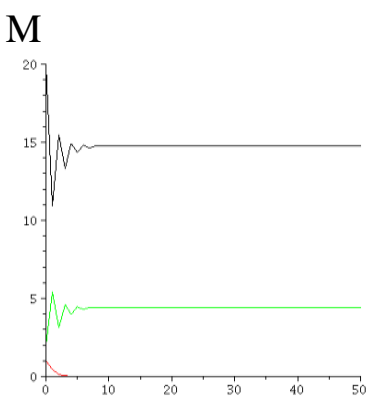

$\mathrm{H}$
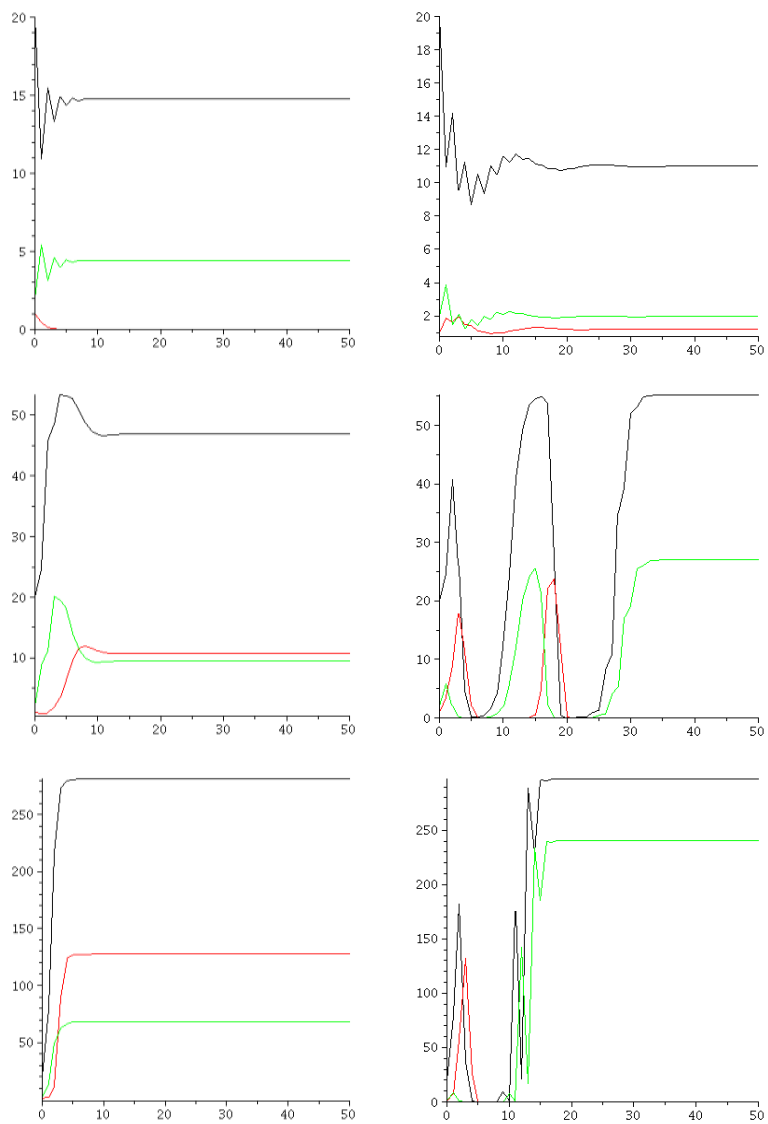

Fig. 5. Simulations representing, high, medium and low host performance and pathogenicity in the Tragopogon pratensis-Puccinia hysterium system where there is a trade-off between transmissibility and disease-induced mortality where mortality in the seedbank is high $\left(b_{0}=0.97\right)$. Each simulation represents - S, - I, - R dynamics. 


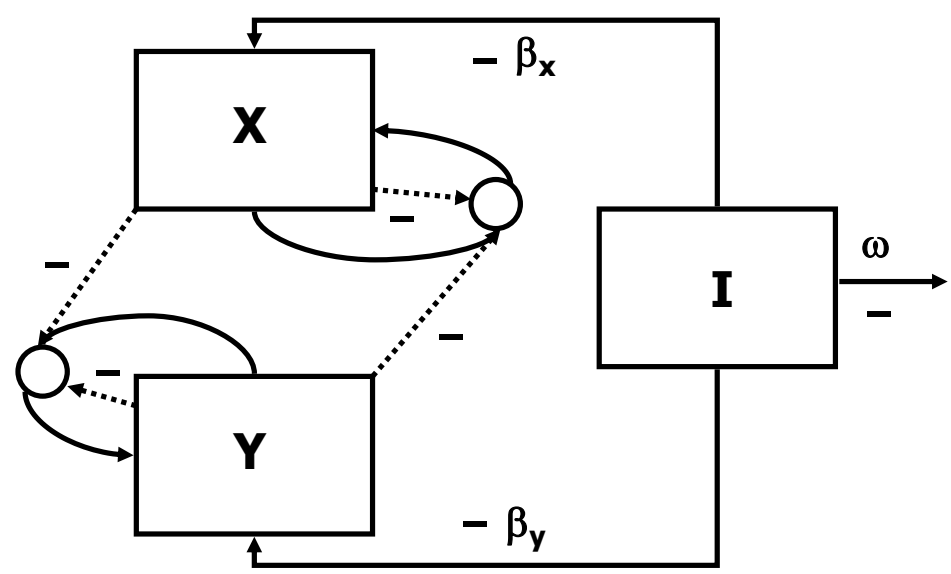

Fig. 6. Schematic representation of competition between two host species $(X$ and $Y$ ) in the presence of a generalist pathogen (I). Infection parameters are $B_{X}$ and $B_{Y}$ on species $X$ and $Y$ respectively. See text and van den Berg \& van den Bosch (2009; Fig.1a) for incorporation of plant intrinsic rates of increase and competition coefficients into the model. 


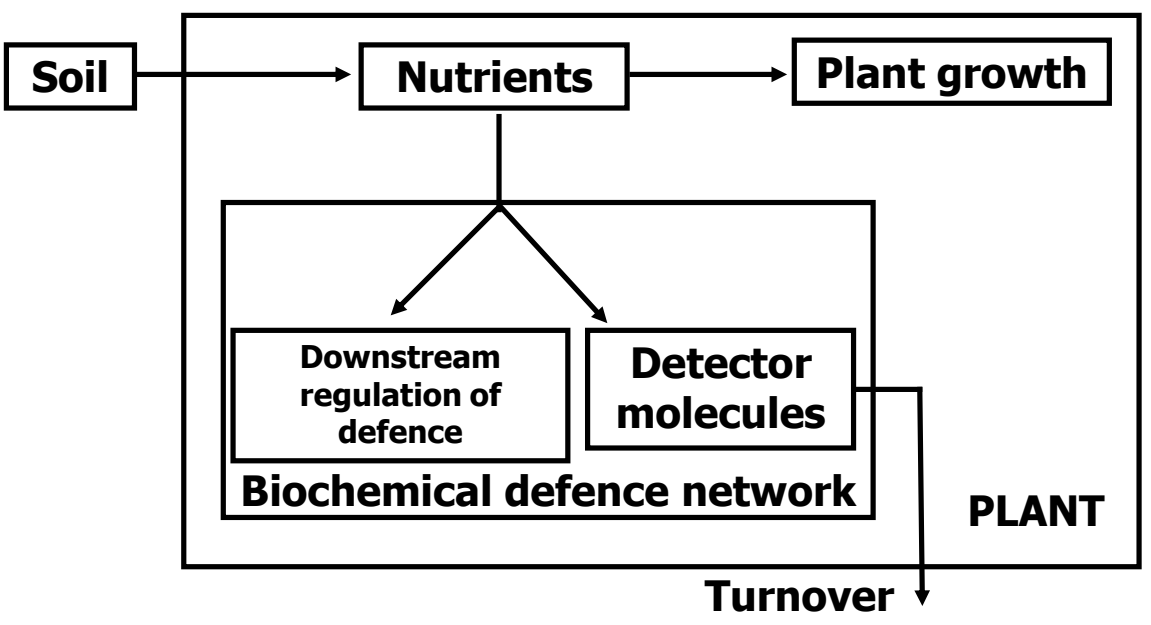

Fig.7. Mechanistic interpretation of the trade-off relationship between plant defence against pathogens and plant growth (van den Berg \& van den Bosch, 2009; Fig. 1b) in relation to nutrient supply. 
Table 1: Selected experimental studies ${ }^{1}$ investigating a range of topics ${ }^{2}$ concerned with the impact of

\begin{tabular}{|c|c|c|}
\hline Topic studied & Plant/pathogen system & References \\
\hline $\begin{array}{l}\text { Disease and annual management } \\
\text { strategies } \\
\text { (mowing/mulching/fallow/grazing) }\end{array}$ & $\begin{array}{l}\text { Permanent grass stands with } \\
\text { Alopecurus pratensis/Puccinia } \\
\text { perplexans and Lathyrus } \\
\text { pratenis/powdery mildew }\end{array}$ & $\begin{array}{l}\text { Vozenilkova et al., 2007; } \\
2008\end{array}$ \\
\hline Interactions with other habitats & $\begin{array}{l}\text { Carex blanda/Anthracoidiae } \\
\text { blanda and Puccinia carici in } \\
\text { woodland and grassland; } \\
\text { Deschampsia flexuosa with } \\
\text { Vaccinium myrtilis/Valdensia } \\
\text { heterodoxa in forest } \\
\text { vegetation; non-sown } \\
\text { grassland species/Blumeria } \\
\text { graminis and Zymoseptoria } \\
\text { tritici in cereal fields; Lolium } \\
\text { arundinaceum/Neotyphodium } \\
\text { coenophialum and grassland to } \\
\text { woodland succession }\end{array}$ & $\begin{array}{l}\text { Finch \& Alexander, 2011; } \\
\text { Strengbom et al., 2002; } \\
\text { Firbank et al., 2003; Rutgers } \\
\text { \& Orr, } 2009\end{array}$ \\
\hline $\begin{array}{l}\text { Manipulative experimentation in } \\
\text { relatively unmanaged grassland } \\
\text { ecosystems }\end{array}$ & $\begin{array}{l}\text { Native and introduced grasses } \\
\text { /barley (cereal) yellow dwarf } \\
\text { viruses in California and N } \\
\text { American Pacific coast; New } \\
\text { Zealand native grasses and } \\
\text { exotic cereal and pasture } \\
\text { viruses }\end{array}$ & $\begin{array}{l}\text { Malstrom et al., 2005, 2007; } \\
\text { Borer et al., 2007, 2009, } \\
\text { 2010; Seabloom et al. , 2009, } \\
\text { 2010, 2013; Power et al., } \\
\text { 2011; Delmiglio et al., } 2010\end{array}$ \\
\hline $\begin{array}{l}\text { Invasion of pathogens into native } \\
\text { grasslands }\end{array}$ & $\begin{array}{l}\text { Invasive and non-invasive } \\
\text { exotic grass species/leaf rust } \\
\text { and herbivory; Commandra } \\
\text { umbellata and Andropogon } \\
\text { gerardii/Puccinia andropogonis } \\
\text { in native prairie; Plantago } \\
\text { lanceolata/Diaporthe adunca } \\
\text { and partial resistance }\end{array}$ & $\begin{array}{l}\text { Han et al., 2008; Barnes et } \\
\text { al., 2005; Linders et al., } 1996\end{array}$ \\
\hline $\begin{array}{l}\text { Biological control of introduced } \\
\text { plant species considered as weeds } \\
\text { in managed grassland }\end{array}$ & $\begin{array}{l}\text { Campuloclinium } \\
\text { macrosephalum/Puccinia } \\
\text { eupatorii; Euphorbia esula/soil- } \\
\text { borne pathogens and insect } \\
\text { root feeding; Parthenium } \\
\text { hysteropherus /facultative and }\end{array}$ & $\begin{array}{l}\text { Goodall et al., 2012; Kremer } \\
\text { et al., 2006; Taye et al., 2004; } \\
\text { de Jong et al, 2002; Franzen } \\
\text { et al., } 1994\end{array}$ \\
\hline
\end{tabular}




\begin{tabular}{|c|c|c|}
\hline & $\begin{array}{l}\text { obligate fungal pathogens and } \\
\text { a phytoplasma; Circium } \\
\text { arvense/Sclerotinia } \\
\text { sclerotiorum and Puccinia } \\
\text { punctiformis }\end{array}$ & \\
\hline $\begin{array}{l}\text { Soil microbes and plant } \\
\text { diversity/disease suppression }\end{array}$ & $\begin{array}{l}\text { Herbaceous plant } \\
\text { communities/mycorrhizal and } \\
\text { non-mycorrhizal infection; } \\
\text { long-term managed grasslands/ } \\
\text { actinobacterial communities; } \\
\text { barley and grassland/ } \\
\text { arbuscular mycorrhizal fungi } \\
\text { and transmission of Bipolaris } \\
\text { sorokiniana ; permanent } \\
\text { grassland and arable } \\
\text { rotations/Rhizoctonia solani }\end{array}$ & $\begin{array}{l}\text { Schnitzer al., 2011; Jenkins et } \\
\text { al., 2009; Sjoberg et al., } \\
\text { 2007; van Elsas et al., } 2002\end{array}$ \\
\hline Fungal endophytes & $\begin{array}{l}\text { Rice pests/Neotyphodium in } \\
\text { grasslands; Bromus } \\
\text { auleticus/Ustilago bullata }\end{array}$ & $\begin{array}{l}\text { Shiba \& Sugawara, 2005, } \\
\text { Vignale et al., } 2013\end{array}$ \\
\hline
\end{tabular}

${ }^{1}$ the examples of experimental studies for each topic are representative, not exhaustive.

${ }^{2}$ the range of topics is illustrative for grassland ecosystems, not exhaustive 
Table 2. Parameter ranges for low, medium and high host performance and pathogenicity used in simulations of Tragopogon pratensis-Puccinia hysterium dynamics.

\begin{tabular}{c|ccc} 
Disease & Low & Medium & High \\
\hline$c$ & 0.1 & 0.3 & 0.8 \\
\hline$p$ & 0.3 & 0.7 & 1.0 \\
B & 0.1 & 0.2 & 0.3 \\
Host & & & \\
\hline$a_{0}$ & 0.2 & 0.3 & 0.5 \\
$a_{1}$ & 100 & 100 & 120 \\
$b_{0}$ & 0.97 & 0.7 & 0.5 \\
$b_{1}$ & 0.4 & 0.3 & 0.1 \\
$d_{0}$ & 0.3 & 0.2 & 0.1 \\
$d_{1}$ & 0.5 & 0.3 & 0.1 \\
$\lambda$ & 1.0 & 0.5 & 0.2 \\
\hline
\end{tabular}

